\title{
Mathematical modeling of temperature variation in breast tissue with and without tumor/cyst during menstrual cycle
}

\author{
Shrestha S., Gurung D. B., Gokul K. C. \\ Department of Mathematics, School of Science, Kathmandu University, \\ Dhulikhel 45200, Nepal
}

(Received 1 December 2020; Revised 17 February 2021; Accepted 20 February 2021)

\begin{abstract}
The thermoregulation of human female body is influenced by hormonal and physiological changes in the body during the menstrual cycle. The fluctuation of estrogen and progesterone hormones, release in the follicular phase and the luteal phase of menstrual cycle, respectively play an important role in the growth of breast ducts and lobules (milk glands). The imbalance of these hormones causes breast tumors/cysts. The body core temperature, blood perfusion and metabolism rate are higher in the luteal phase than the follicular phase of menstrual cycle. In the present work, a tumor/cyst is assumed to be in the glandular layer. A two-dimensional Pennes bioheat equation is solved to find the temperature variation in breast tissue with and without tumor/cyst during the menstrual cycle by using the finite element method. The results show that the temperature of each layer of breast tissue in the luteal phase is higher than the follicular phase in the case of normal breast, tumorous breast and breast with cyst.
\end{abstract}

Keywords: breast tumor, menstrual cycle, temperature variation, FEM.

2010 MSC: 92C35, 80A19, 35Q79

DOI: $10.23939 / \mathrm{mmc} 2021.02 .192$

\section{Introduction}

The thermoregulation of female human body is influenced by hormonal and physiological changes in the body during the menstrual cycle. The body temperature is sensitive to the sex hormones, which are released by the uterus during the menstrual cycle. During the menstrual cycle, the hypothalamus of pituitary gland produces follicle-stimulating hormone (FSH) and Luteinizing hormone (LH), which promote ovulation and stimulate the ovaries to produce sex hormones - estrogen and progesterone. These hormones stimulate the uterus and breasts to prepare for possible fertilization. The menstrual cycle is a natural process of a female body, which occurs due to hormonal changes in reproductive system. The first menstruation of the girl begins at the age of $12-15$ and it ends with menopause [1]. It is a monthly series, which is counted from the first day of one period to ends with the start of the next period. The length of the menstrual cycle may vary from month to month and from woman to woman. The average length of menstrual cycle is 28 days (shortest 21 and longest 35 days). The menstrual cycle consists of two phases: follicular (pre-ovulation period, first half of the menstrual cycle) and luteal (post-ovulation period, second half of the menstrual cycle). The follicular phase is starting with a low level of estrogen and progesterone hormone. During the follicular phase (before release of the egg), follicles produce estrogen and its level rises up to the beginning of ovulation (egg release), which lasts 16 to 32 hours [2]. Estrogen hormone plays an important role in development of normal breast tissue [3]. After ovulation, estrogen's level decreases. During the luteal phase, the follicle closes and forms a corpus luteum, which produces mainly progesterone and some estrogen. If the egg is unable to fertilize, the corpus luteum degenerates and stops the production of hormones. Then estrogen and progesterone hormone level decreases, which causes the onset of menses.

This work was supported by the University Grants Commission (UGC) Nepal, under the UGC PhD Fellowship (Award No: PhD $/ 74-75 / \mathrm{S} \& \mathrm{~T}-11)$ to the first author. 
Breasts are accessory organs of the female reproductive system [4,5]. Human breast tissue begins to develop in the fourth week of fetal life. Before puberty, the female breast is composed with branching of ductal system (lacks of lobular units). The breasts of female start to grow and develop at puberty due to estrogen and progesterone hormones. The glandular layer of breast tissue increases with the first menstrual cycle of girls. During the menstrual cycle, breast tissue responds to changing levels of estrogen and progesterone hormones. The fluctuation of estrogen hormone causes the growth of breast ducts in size and progesterone hormone causes the growth of breast lobules (milk glands). This causes female breast pain, soreness and swelling before menses.

The imbalance of estrogen and progesterone hormones in the human female body causes a breast lump. It can developed in any part of the breast. This lump can be either cyst or tumor. Breast cyst is a fluid-filled sac, which is normally developed in milk glands. The physical properties of a cyst are the same as the properties of water [6]. Most of the breast cysts are benign (non-cancerous). During menstrual cycle, estrogen stimulates breast tissue to increase cell division [3]. When cell division is damaged, it causes tumor. Tumors may be benign or malignant (cancerous).

Hessemer and Bruck [7] experimentally observed the influence of menstrual cycle on shivering, skin blood flow, and sweating responses in external cold and heat exposure in middle of luteal phase and in the early follicular phase of the menstrual cycle. They reported that Serum progesterone concentrations in luteal phase and follicular phase were averaged $46.0 \mathrm{nmol} / 1$ and $0.9 \mathrm{nmol} / 1$, respectively when the luteal phase and follicular phase core temperature difference was maximal. They concluded that female luteal phase temperature was higher than follicular phase. Acharya et al. [8] developed one dimensional heat transfer model based on sweating responses to change of body temperature. They compared the temperature profile of female luteal and follicular phases of menstrual cycle and temperature profile of male. They concluded that the male body temperature was higher than female follicular temperature and lower than female luteal temperature. Makrariya and Pardasani [9] studied the thermal changes in a woman breast during menstrual cycle in different stages of breast development. They conclude that the thermal discomfort in luteal phase was higher than follicular phase. Makrariya and Adlakha [10] studied thermographic patterns in women breast with and without tumor during menstrual cycle. Whelan et al. [11] observed the risk of breast cancer during menstrual cycle. They conducted the information by mail survey among 997 women who had recorded menstrual events. They found that a risk factor for breast cancer may be a pattern of short (less than 26 days) or long (greater or equal to 34 days) menstrual cycle during reproductive life. Nakamur et al. [12] concluded that the body core temperature was higher in the luteal phase than follicular phase on their experiments of eight healthy young women. Bosetti et al. [13] studied on the benign ovarian cysts and risk of breast cancer by analyzing the data from three hospitals. Lee et al. [14] experimentally compared the local sweat rates and cutaneous vasodilatation during heat exposure in women with a regular full menstrual cycle. They found that the sweating rate and skin blood flow were greater in the luteal phase compared to follicular one.

The aim of the presented paper is to find the temperature variation of female breast tissue with and without tumor/cyst during menstrual cycle by using two-dimensional finite element method.

\section{Model formulation}

The five layers epidermis, dermis, subcutaneous tissue, glandular layer and muscle with thoracic wall are assumed in breast with hemi-spherical shape. The domain of the breast is assumed to be $72 \mathrm{~mm}$ from areola to the body core [15-19] with thickness $1.5 \mathrm{~mm}, 2 \mathrm{~mm}, 1.5 \mathrm{~mm}, 45 \mathrm{~mm}$ and $22 \mathrm{~mm}$ of epidermis, dermis, subcutaneous tissue, glandular layer and muscle with thoracic wall, respectively. The $\mathrm{X}$-axis is central line of the breast. The part of the breast is symmetrical about the central line. In the study, a tumor/cyst is assumed in glandular layer at central line of the breast. This is because most of the breast tumor/cyst develops in lobules and milk ducts of glandular layer and medically glandular is known as breast. 


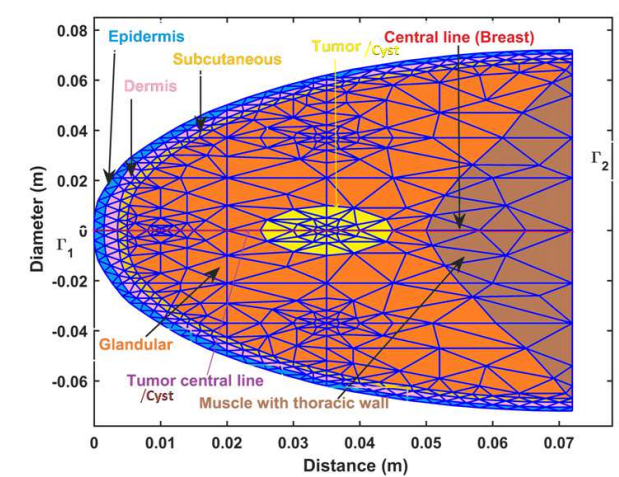

Fig. 1. Schematic diagram of element-wise 2-D discretization of breast tissue with tumor.
Figure 1 represents the schematic diagram of element wise two-dimensional discretization of breast tissue with tumor/cyst. The diameter of tumor/cyst is taken $20 \mathrm{~mm}$ having center $(35,0)$.

The finite element method is used for numerical solution. The whole domain of the breast is divided into 862 triangular finite elements. The epidermal, dermal and subcutaneous layers of SST region are divided into 128, 128, 130 triangular finite elements, respectively. The glandular layer, tumor/cyst and muscle with thoracic wall are divided into 382,52 and 42 triangular finite elements, respectively.

\subsection{Governing equation}

The Pennes bioheat equation [20] describes the energy balance between metabolism and blood perfusion in a living tissue. In the study, this model is used for numerical solution. The simplified form of twodimensional bioheat equation is:

$$
K \Delta U+B_{p}\left(U_{b}-U\right)+M_{h}+M_{t}=0,
$$

where $K$ is thermal conductivity of tissue $\left[\mathrm{W} / \mathrm{m}{ }^{\circ} \mathrm{C}\right], \Delta=\nabla^{2}$ is Laplacian operator, $B_{p}=w_{b} c_{b} \rho_{b}$ $\left[\mathrm{W} / \mathrm{m}^{3 \circ} \mathrm{C}\right], w_{b}$ is volumetric blood perfusion rate per unit volume $\left[\mathrm{s}^{-1}\right], c_{b}$ is specific heat of the blood $\left[\mathrm{J} / \mathrm{kg}^{\circ} \mathrm{C}\right], \rho_{b}$ is density of the blood $\left[\mathrm{kg} / \mathrm{m}^{3}\right], U_{b}$ is arterial blood temperature $\left[{ }^{\circ} \mathrm{C}\right], U$ is local temperature of tissue $\left[{ }^{\circ} \mathrm{C}\right], M_{h}$ is metabolic heat generation rate of healthy tissue $\left[\mathrm{W} / \mathrm{m}^{3}\right]$ and $M_{t}$ is extra heat generation due to tumor $\left[\mathrm{W} / \mathrm{m}^{3}\right] . M_{t}=0$ for normal breast tissue.

\subsection{Boundary condition}

The heat loss from breast skin is caused by convection, radiation and sweat evaporation. The mixed boundary condition $[18,19,21]$ is used in outer surface of the breast:

$$
\Gamma_{1}: K \frac{\partial U}{\partial \eta}=h_{c}\left(U-U_{R}\right)+L E
$$

where $\eta$ is the normal direction to the surface boundary, $h_{c}$ is combined heat transfer coefficient due to convection and radiation $\left[\mathrm{W} / \mathrm{m}^{2}{ }^{\circ} \mathrm{C}\right], U_{R}$ is room temperature $\left[{ }^{\circ} \mathrm{C}\right], L$ is Latent heat of evaporation $[\mathrm{J} / \mathrm{kg}]$ and $E$ is sweat evaporation rate $\left[\mathrm{kg} / \mathrm{m}^{2} \mathrm{sec}\right]$.

Thermoregulation of human body maintains body core temperature at $37^{\circ} \mathrm{C}\left( \pm 0.6^{\circ} \mathrm{C}\right)$ by physical (conduction, convection, radiation, evaporation) and physiological (blood flow and metabolism) factors. The body core temperature is sensitive to female sex hormones, which are released during the menstrual cycle. Estrogen hormone has a cooling effect on the body and it cools the body temperature before ovulation [8]. The plasma concentration rises during the luteal phase [8,22]. So, progesterone hormone warms the body temperature after ovulation to menstruation. Stephenson and Kolka [23] experimentally observed the thermoregulation in women at two different times of day during the follicular and luteal phases of the menstrual cycle. They found the resting body core temperatures range from $36.76^{\circ} \mathrm{C}$ during early morning in the follicular phase to $37.48^{\circ} \mathrm{C}$ during the afternoon of the luteal phase. The same results is used in the study. Thoracic wall is inner boundary of the breast and 
Dirichlet boundary condition is used in this part:

$$
\begin{array}{ll}
\Gamma_{2}: B_{t}, & \\
B_{t}=36.76^{\circ} \mathrm{C} & \text { for follicular phase, } \\
B_{t}=37.48^{\circ} \mathrm{C} & \text { for luteal phase, }
\end{array}
$$

where $B_{t}$ is body core temperature.

For continuity, the temperatures at the interface $i$ of breast tissue layers are defined as:

$$
\begin{aligned}
K_{i} \frac{\partial U_{i}}{\partial \eta} & =K_{i+1} \frac{\partial U_{i+1}}{\partial \eta} \\
U_{i} & =U_{i+1} .
\end{aligned}
$$

Similarly, for interface of tumor and healthy breast tissue,

$$
\begin{aligned}
K_{h} \frac{\partial U_{h}}{\partial \eta} & =K_{t} \frac{\partial U_{t}}{\partial \eta} \\
U_{h} & =U_{t} .
\end{aligned}
$$

Here, the suffices $h$ and $t$ are used for healthy and tumor.

\subsection{Existence and uniqueness of weak solution of model equation}

The governing equation is:

$$
-K \Delta U+B_{p} U=f \quad \text { in } \quad \Omega,
$$

where, $f=B_{p} U_{b}+M_{h}+M_{t}$.

With the boundary conditions:

$$
\begin{aligned}
K \frac{\partial U}{\partial \eta} & =h_{c}\left(U-U_{R}\right)+L E & \text { on } & \Gamma_{1}, \\
U_{b} & =B_{t} & \text { on } & \Gamma_{2}, \\
\partial \Omega & =\Gamma_{1} \cup \Gamma_{2}, & \Gamma_{1} \cap \Gamma_{2}=\phi . &
\end{aligned}
$$

Multiplying (6) by the test function $v \in V=H^{1}(\Omega)$ and integrating over the domain $\Omega$ yields

$$
K \int_{\Omega} \nabla U \cdot \nabla v d x d y+\int_{\Omega} B_{p} U v d x d y=\int_{\Omega} f v d x d y+W,
$$

where,

$$
W=\int_{\partial \Omega} v K \frac{\partial U}{\partial \eta} d x d y
$$

Thus, the weak form or variational problem of governing equation (6) is:

find $U \in V=H^{1}(\Omega)$ such that

$$
a(U, v)=\ell(v)+W \quad \text { for all } \quad v \in V=H^{1}(\Omega)
$$

where,

$$
a(U, v)=K \int_{\Omega} \nabla U \cdot \nabla v d x d y+\int_{\Omega} B_{p} U v d x d y
$$

Mathematical Modeling and Computing, Vol. 8, No. 2, pp. 192-202 (2021) 


$$
\ell(v)=\int_{\Omega} f v d x d y, \quad v \in V=H^{1}(\Omega)
$$

(i) As $a(U, v)=a(v, U), a(\cdot, \cdot)$ is symmetric.

(ii) For $U_{1}, U_{2}, v \in V$ and $\alpha_{1}, \alpha_{2} \in \mathbb{R}$ $a\left(\alpha_{1} U_{1}+\alpha_{2} U_{2}, v\right)=\alpha_{1} a\left(U_{1}, v\right)+\alpha_{2} a\left(U_{2}, v\right)$

and, for $U, v_{1}, v_{2} \in V$ and $\beta_{1}, \beta_{2} \in \mathbb{R}$ $a\left(U, \beta_{1} v_{1}+\beta_{2} v_{2}\right)=\beta_{1} a\left(U, v_{1}\right)+\beta_{2} a\left(U, v_{2}\right)$.

Therefore, $a(\cdot, \cdot)$ is a bilinear functional on $V \times V$.

(iii) Since $|a(U, v)| \leqslant(K n+P)\|U\|_{H^{1}(\Omega)}\|v\|_{H^{1}(\Omega)}, a(\cdot, \cdot)$ is bounded and hence continuous.

(iv) Since $a(v, v) \geqslant(K C+P)\|v\|_{H^{1}(\Omega)}^{2}, C>0, a(\cdot, \cdot)$ is Coercive or V-elliptic.

(v) $\ell(\cdot)$ is bounded since $|\ell(v)| \leqslant \xi\|v\|_{H^{1}(\Omega)}, \xi>0$.

(vi) For $v_{1}, v_{2} \in V$ and $\alpha_{1}, \alpha_{2} \in \mathbb{R}, \ell\left(\alpha_{1} v_{1}+\alpha_{2} v_{2}\right)=\alpha_{1} \ell\left(v_{1}\right)+\alpha_{2} \ell\left(v_{2}\right)$.

Therefore, $\ell(\cdot)$ is linear.

Here, $a(\cdot, \cdot): V \times V \longrightarrow \mathbb{R}, V=H^{1}(\Omega)$ is bilinear, bounded and V-elliptic. Also, $\ell: V \rightarrow \mathbb{R}$ is a bounded linear functional and $\ell \in V^{*}$, the dual space of $V$. Hence by the Lax-Milgram theorem, there exists a weak formulation of Eq. (6), and it has a unique solution.

Since $a(\cdot, \cdot)$ is symmetric, the variational problem (10) is equivalent to the minimization problem:

$$
I[U(x, y)]=\frac{1}{2} a(U, U)-\ell(U) .
$$

The variational form of the partial differential Eq. (1) together with its boundary condition (2) in two-dimensions is given by

$$
\begin{aligned}
I[U(x, y)]= & \frac{1}{2} \iint_{\Omega}\left[K\left(\left(\frac{\partial U}{\partial x}\right)^{2}+\left(\frac{\partial U}{\partial y}\right)^{2}\right)+P\left(U_{b}-U\right)^{2}-2 M U\right] d x d y \\
& +\frac{1}{2} \int_{\Gamma_{1}}\left[h_{c}\left(U-U_{R}\right)^{2}+L E U\right] d \Gamma_{1},
\end{aligned}
$$

where, $M=M_{h}+M_{t}$.

The Lagrange linear interpolation functions are used to approximate the solution of the triangular finite elements [24,25].

For minimization,

$$
\frac{d I}{d U_{i}}=0
$$

where, $U_{i}$ represents the temperature in $i^{\text {th }}$ triangular mesh.

The system of Eq. (12) can be written in matrix form:

$$
U=A^{-1} B
$$

where, $U=\left[U_{i}\right]$ is $N \times 1$ vector, $B=\left[B_{i}\right]$ is $N \times 1$ load vector matrix and $A$ is $N \times N$ conductance matrix respectively, $N$ is the total number of nodal points in discretization of the domain. The MATLAB programming language is used for simulation.

\section{Results and discussion}

The metabolic rate in luteal phase is about $5-6 \%$ higher than follicular phase of females $[7,8]$. So in the study, $6 \%$ more metabolic rate is used for luteal phase than follicular phase. The parameter values in the numerical simulations are taken as in Table 1 and 2. 
Table 1. Values of thermal conductivity, perfusion and metabolism.

$\left.\begin{array}{|c|c|c|c|}\hline \begin{array}{c}\text { Layers of } \\ \text { Breast } \\ \text { Tissue }\end{array} & \begin{array}{c}\text { Thermal } \\ \text { Conductivity } \\ K\left(\mathrm{~W} / \mathrm{m}^{\circ} \mathrm{C}\right)\end{array} & \begin{array}{c}\text { Perfusion } \\ w_{b} c_{b} \rho_{b} \\ \left(\mathrm{~W} / \mathrm{m}^{3}{ }^{\circ} \mathrm{C}\right)\end{array} & \begin{array}{c}\text { Metabolism } \\ M \\ \left(\mathrm{~W} / \mathrm{m}^{3}\right)\end{array} \\ \hline \begin{array}{c}\text { Muscle with } \\ \text { Thoracic } \\ \text { wall }\end{array} & 0.48 & \begin{array}{c}b=1538 \text { (Follicular) } \\ b=2197 \text { (Luteal) }\end{array} & \begin{array}{c}m=665 \text { (Follicular) } \\ m=705 \text { (Luteal) } \\ {[8,9]}\end{array} \\ \hline \text { Epidermis } & 0.20934 & 0 \\ & {[18,19,28]} & 0 & {[18,19,26]}\end{array}\right)$

Table 2. Parameter values used in Model.

\begin{tabular}{|c|c|}
\hline Parameters & Values \\
\hline Heat transfer coefficient $\left(h_{c}, \mathrm{~W} / \mathrm{m}^{2}{ }^{\circ} \mathrm{C}\right)$ & $13.5[17,19,26]$ \\
\hline Latent heat of evaporation $(L, \mathrm{~J} / \mathrm{kg})$ & $2.4 \cdot 10^{6}[18,19,28]$ \\
\hline Sweat evaporation rate $\left(E, \mathrm{~kg} / \mathrm{m}^{2} \mathrm{sec}\right)$ & $3.0806 \cdot 10^{-6}[30]$ \\
\hline Room temperature $\left(U_{R},{ }^{\circ} \mathrm{C}\right)$ & $25[30]$ \\
\hline
\end{tabular}

\subsection{Temperature profile of breast tissue}

Figures 2 and 3 show the temperature profiles of normal breast tissue in follicular phase and luteal phase, respectively. From the exhibited graphs, the skin surface temperatures of breast tissue in follicular and luteal phases are $31.60^{\circ}$ and $32.39^{\circ}$ respectively. Similarly, the interface temperatures of epidermis and dermis, dermis and subcutaneous, subcutaneous and glandular, glandular and muscle of breast tissue in follicular and luteal phases are $32.29^{\circ}, 32.90^{\circ}, 33.23^{\circ}, 36.64^{\circ}$ and $33.15^{\circ}, 33.83^{\circ}, 34.20^{\circ}$, $37.40^{\circ}$ respectively. This shows that the temperature of breast tissue increases from skin surface to body core in both phases of menstrual cycle. The results show that the temperature of each layers of breast tissue in luteal phase is higher than the follicular phase. The similar behavior of the temperature is shown in breast tissue in presence of tumor and cyst (Figs. 4-7).

Also, it is observed from the graphs that the skin surface temperature of normal breast in luteal phase is higher than follicular phase by $0.79^{\circ} \mathrm{C}$. Hessemer and Bruck [7] and Lee et al. [14] found the mean skin temperature in luteal phase was averaged $0.59^{\circ} \mathrm{C}$ and $2.5^{\circ} \mathrm{C}$ respectively higher than follicular phase. Acharya et al. [8] observed the skin temperature in luteal phase was higher by $0.68-1.18^{\circ} \mathrm{C}$ than follicular phase at different room temperatures. 


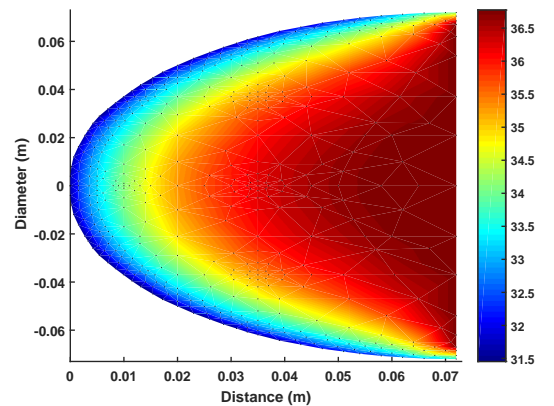

Fig. 2. Temperature profiles of normal breast tissue in follicular phase.

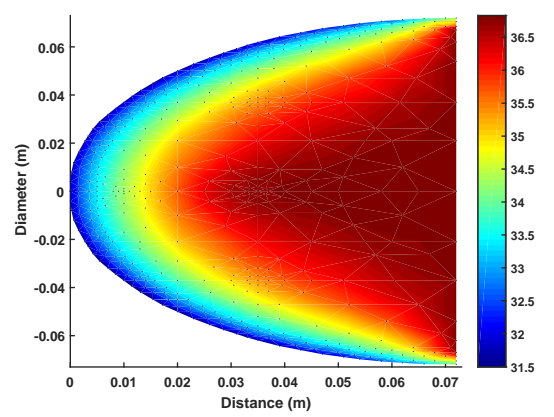

Fig. 4. Temperature profiles of tumorous breast tissue in follicular phase.

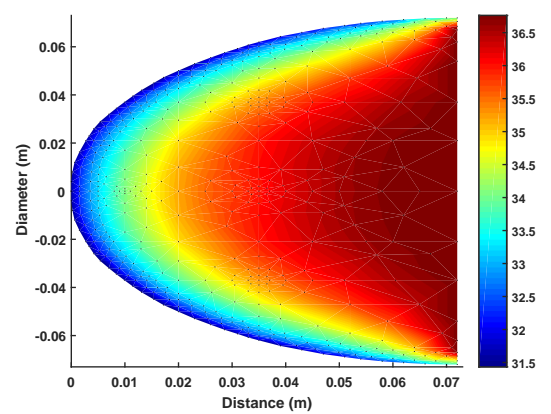

Fig. 6. Temperature profiles of breast tissue with cyst in follicular phase.

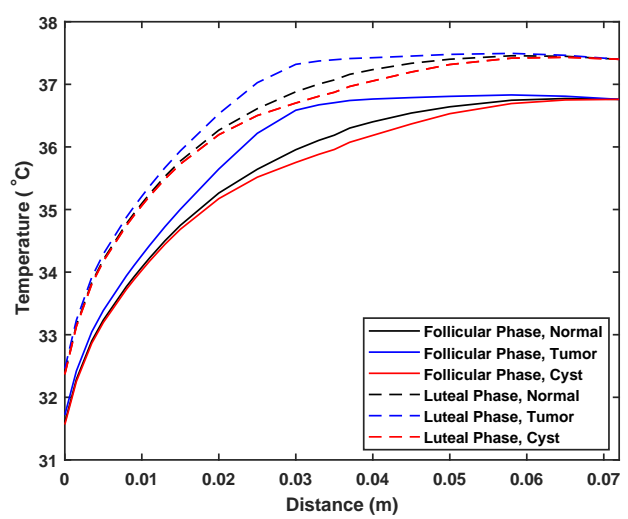

Fig. 8. Temperature profiles of breast tissue with and without tumor/cyst.

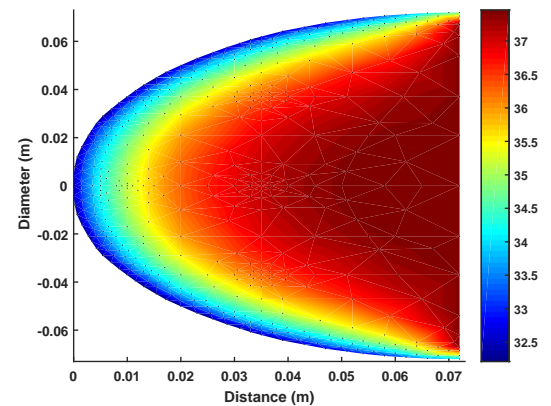

Fig. 3. Temperature profiles of normal breast tissue in luteal phase.

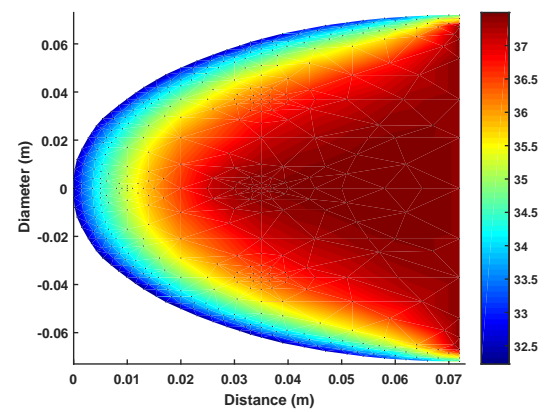

Fig. 5. Temperature profiles of tumorous breast tissue in luteal phase.

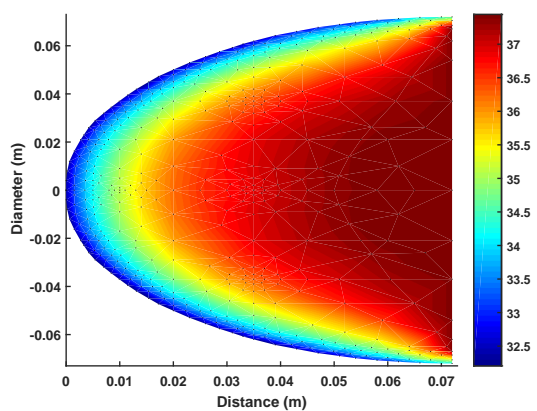

Fig. 7. Temperature profiles of breast tissue with cyst in luteal phase.

Temperature profiles of breast tissue with and without tumor/cyst are shown in Fig. 8. The results show that the temperature of tumorous breast tissue increases from skin surface to tumor region due to high impact of perfusion and metabolic rate in tumor and then it maintains body core temperature in both phases of menstrual cycle. The graph shows that the temperature of each layer of tumorous breast is higher than normal breast in both phases of menstrual cycle. The skin surface temperatures of tumorous breast in follicular and luteal phases are higher than normal breast by $0.12^{\circ} \mathrm{C}$ and $0.07^{\circ} \mathrm{C}$ respectively. The difference of skin surface temperature of tumorous and normal breast is small because tumor 
lies $35 \mathrm{~mm}$ far from areola. In our previous article $[18,19]$, we observed that increase in tumor distance from areola decreases the skin surface temperature.

In the presence of cyst, the skin surface temperature of breast in follicular and luteal phases are lower than normal breast by $0.03^{\circ} \mathrm{C}$. The results show that the temperature in cyst region is lower than normal breast in both phases of menstrual cycle due to no blood perfusion and metabolism in cyst.

\subsection{Sensitivity analysis of temperature profiles of breast tissue for different heat transfer coeffi- cients and different room temperatures}

Figures 9-11 represent the temperature profiles of normal breast, tumorous breast and breast with cyst, respectively at different heat transfer coefficients $\left(h_{c}\right) 10 \mathrm{~W} / \mathrm{m}^{2}{ }^{\circ} \mathrm{C}, 13.5 \mathrm{~W} / \mathrm{m}^{2}{ }^{\circ} \mathrm{C}$ and $16 \mathrm{~W} / \mathrm{m}^{2}{ }^{\circ} \mathrm{C}$. The results show that increase in heat transfer coefficient in both phases of menstrual cycle decreases the temperature of breast with and without tumor/cyst. The skin surface temperatures in luteal phase are higher than follicular phase by $0.81^{\circ} \mathrm{C}, 0.79^{\circ} \mathrm{C}, 0.78^{\circ} \mathrm{C}$ in normal breast, $0.76^{\circ} \mathrm{C}, 0.75^{\circ} \mathrm{C}, 0.72^{\circ} \mathrm{C}$ in tumorous breast and $0.81^{\circ} \mathrm{C}, 0.80^{\circ} \mathrm{C}, 0.78^{\circ} \mathrm{C}$ in case of cyst at heat transfer coefficient $10 \mathrm{~W} / \mathrm{m}^{2}{ }^{\circ} \mathrm{C}$, $13.5 \mathrm{~W} / \mathrm{m}^{2}{ }^{\circ} \mathrm{C}, 16 \mathrm{~W} / \mathrm{m}^{2}{ }^{\circ} \mathrm{C}$ respectively.

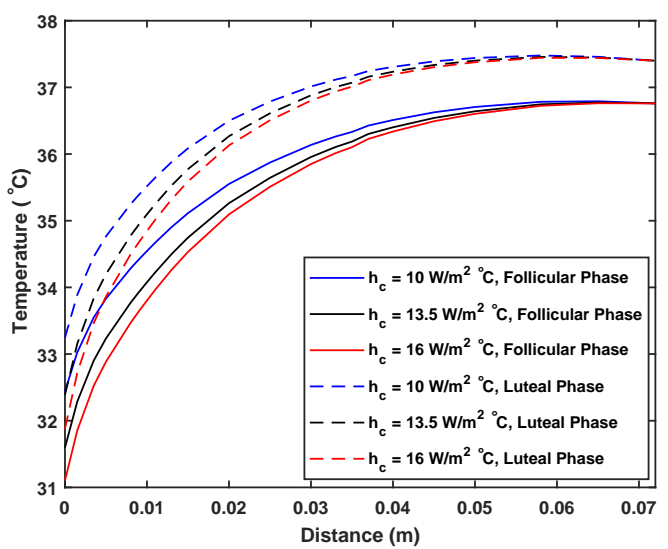

Fig. 9. Temperature profiles of normal breast tissue at different heat transfer coefficients $\left(h_{c}\right)$.

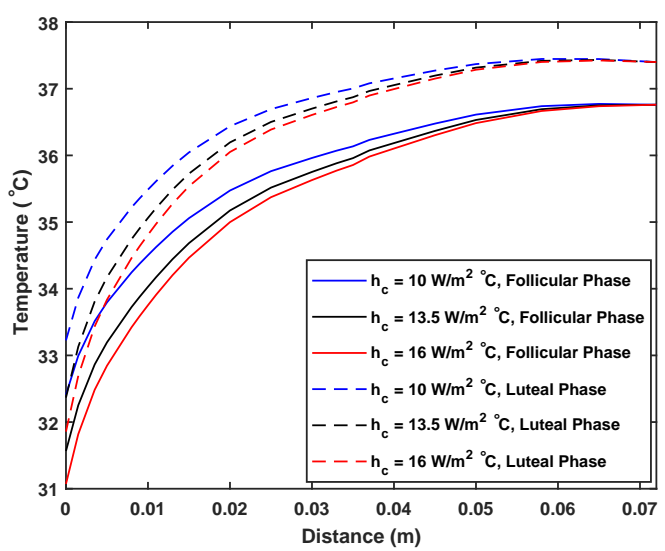

Fig. 11. Temperature profiles of breast tissue with cyst at different heat transfer coefficients $\left(h_{c}\right)$.

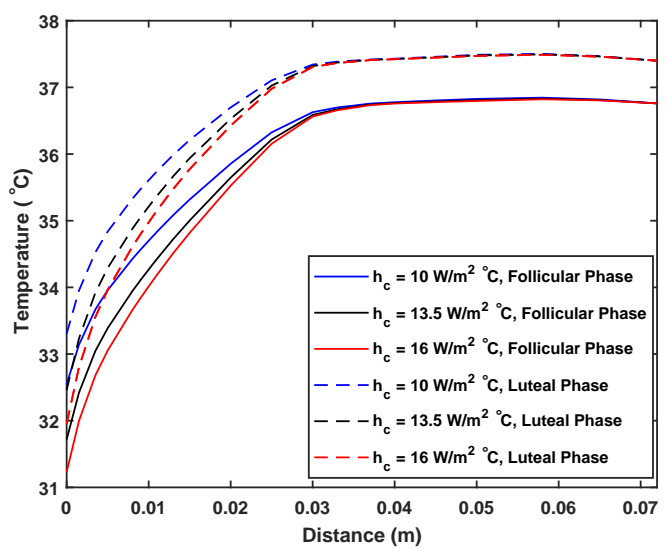

Fig. 10. Temperature profiles of tumorous breast tissue at different heat transfer coefficients $\left(h_{c}\right)$.

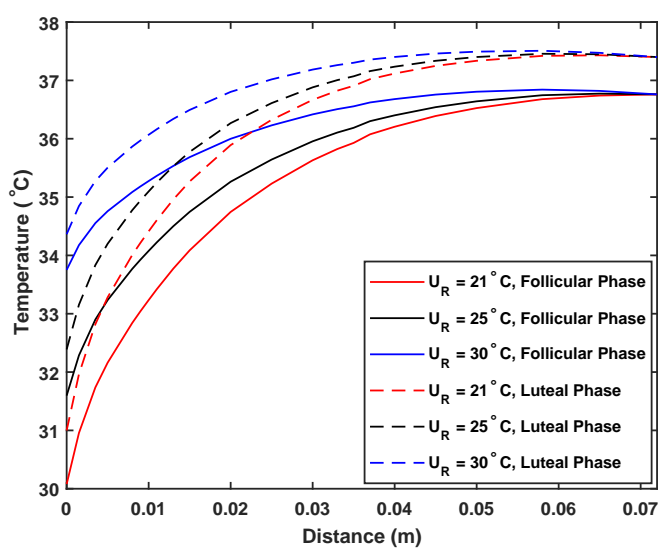

Fig. 12. Temperature profiles of normal breast tissue at different room temperatures $\left(U_{R}\right)$.

The temperature profiles of the breast tissue at different room temperatures $\left(U_{R}\right) 21^{\circ} \mathrm{C}, 25^{\circ} \mathrm{C}$, $30^{\circ} \mathrm{C}$ with sweat evaporation rates $0 \mathrm{~kg} / \mathrm{m}^{2} \mathrm{sec}, 3.0806 \times 10^{-6} \mathrm{~kg} / \mathrm{m}^{2} \mathrm{sec}, 3.6139 \times 10^{-6} \mathrm{~kg} / \mathrm{m}^{2} \mathrm{sec}$ are 
shown in Figs. 12-14 in the case of normal breast, tumorous breast and breast with cyst, respectively. The results show that increase in room temperature in both phases of menstrual cycle increases the temperature of breast with and without tumor/cyst. The skin surface temperatures in luteal phase are higher than in follicular phase by $0.92^{\circ} \mathrm{C}, 0.79^{\circ} \mathrm{C}, 0.61^{\circ} \mathrm{C}$ in normal breast, $0.85^{\circ} \mathrm{C}, 0.73^{\circ} \mathrm{C}, 0.58^{\circ} \mathrm{C}$ in tumorous breast and $0.93^{\circ} \mathrm{C}, 0.81^{\circ} \mathrm{C}, 0.62^{\circ} \mathrm{C}$ in the case of cyst at different room temperatures $21^{\circ} \mathrm{C}$, $25^{\circ} \mathrm{C}, 30^{\circ} \mathrm{C}$, respectively.

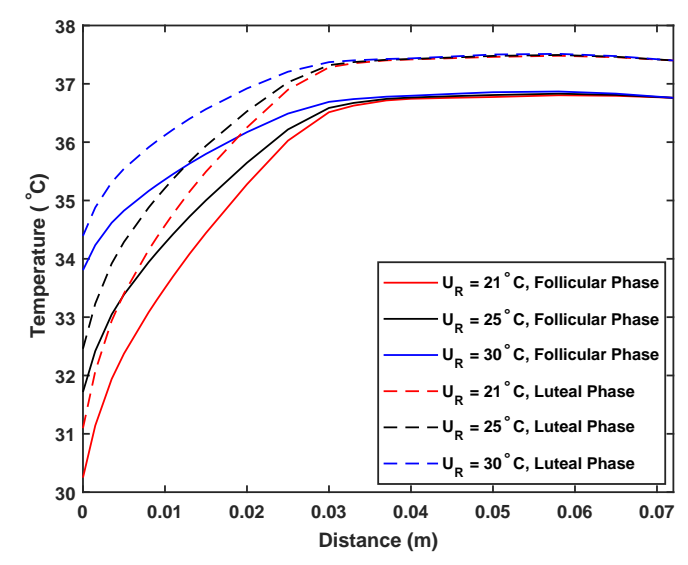

Fig. 13. Temperature profiles of tumorous breast tissue at different room temperatures $\left(U_{R}\right)$.

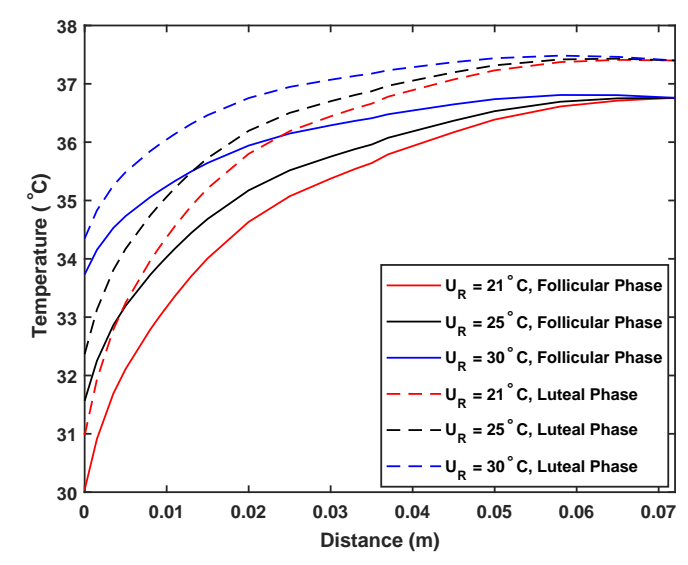

Fig. 14. Temperature profiles of breast tissue with cyst at different room temperatures $\left(U_{R}\right)$.

\section{Conclusions}

The two-dimensional bioheat equation based on the steady state temperature distribution of the female breast with and without tumor is studied in follicular and luteal phases of menstrual cycle. The results show that the temperature of each layer of breast tissue with and without tumor/cyst in the luteal phase is higher than in the follicular phase. The increase in the heat transfer coefficient results in the decrease in the temperature of breast with and without tumors/cysts in both phases of menstrual cycle. The temperatures of normal and tumorous breast are increased when room temperature is increased during the menstrual cycle. The similar behavior of temperature is shown in the case of cysts. The temperature of tumor region is higher than normal but the temperature of cyst region is lower than the temperature of normal breast.

\section{Acknowledgement}

We would like to acknowledge University Grants Commission, Nepal, and all anonymous reviewers and editors for their many insightful comments and suggestions for the improvement of the paper.

[1] Schuiling K. D., Likis F. E. Women's Gynecologic Health. Jones and Bartlett Publishers (2011).

[2] Knudtson K., McLaughlin J. E. Menstrual Cycle, Women's Health Issues. MSD Manuals (2019).

[3] Mufudza C., Sorofa W., Chiyaka E. T. Assessing the Effects of Estrogen on the Dynamics of Breast Cancer. Computational and Mathematical Methods in Medicine. 8, 1-14 (2012).

[4] Breast, Contemporary Health Issues. https://courses. lumenlearning. com/suny-contemporaryhealthissues/chapter/breasts/.

[5] Waugh A., Grant A. Ross \& Wilson Anatomy and Physiology in Health and Illness. Elsevier (2018).

[6] Gambini B., Kruglenko E., Wójcik J. Relationship between Thermal and Ultrasound fields in Breast tissue in vivo. Hydroacoustics. 18, 53-58 (2015). 
[7] Hessemer V., Bruck K. Influence of Menstrual cycle on Shiverings, Skin Blood flow and Sweating responses measured at night. Journal of Applied Physiology. 59, 1902-1910 (1985).

[8] Acharya S., Gurung D. B., Saxena V. P. Mathematical Modeling of Sex Related Differences in the Sensitivity of the Sweating Heat Responses to Change in Body Temperature. BJMCS. 12 (4), 1-11 (2016).

[9] Makrariya A., Adlakha N. Numerical Simulation of Thermal Changes in Tissues of Woman's Breast during Menstrual cycle in Different Stages of its Development. International Journal of Simulation and Process Modelling. 14 (4), 348-359 (2019).

[10] Makrariya A., Adlakha N. Thermographic Pattern's in Women's Breast due to Uniformly Perfused Tumors and Menstrual Cycle. Communications in Mathematical Biology and Neuroscience. 14, 1-20 (2019).

[11] Whelan E. A., Sandier D. P., Root J. L., Smith K. R., Weinberg C. R. Menstrual Cycle Patterns and Risk of Breast Cancer. American Journal of Epidemiology. 140 (12), 1081-1090 (1994).

[12] Nakamura M. M., Yasuhara S., Nagashima K. Effect of menstrual cycle on thermal perception and autonomic thermoregulatory responses during mild cold exposure. Journal of Physiological Sciences. 65, 339-347 (2015).

[13] Bosetti C., Scotti L., Negri E., Talamini R., Levi F., Franceschi S., Montella M., Giacosa A., Vecchia C. L. Benign Ovarian cysts and Breast cancer risk. Int. J. Cancer. 119, 1679-1682 (2006).

[14] Lee H., Petrofsky J., Shah N., Awali A., Shah K., Alotaibi M., Yim J. Higher Sweating Rate and Skin Blood Flow during the Luteal Phase of the Menstrual Cycle. Tohoku J. Exp. Med. 234 (2), 117-122 (2014).

[15] Mital M., Pidaparti R. M. Breast Tumor Simulation and Parameters Estimation Using Evolutionary Algorithms. Hindawi Publishing Corporation Modelling and Simulation in Engineering. 2008, Article ID 756436, 1-6 (2008).

[16] Ng E. Y. K., Sudarshan N. M. An Improved Three-Dimensional direct numerical Modeling and Thermal Analysis of a Female Breast with Tumor. Proceedings of the Institution of Mechanical Engineers. Part H, Journal of Engineering in Medicine. 215 (1), 25-37 (2001).

[17] Osman M. M., Afify E. M. Thermal Modeling of the Normal Woman's Breast. Journal of Biomechanical Engineering. 106 (2), 123-130 (1984).

[18] Shrestha S., Gokul K. C., Gurung D. B. Transient Bioheat Equation in Breast Tissue: Effect of Tumor Size and Location. Journal of Advances in Applied Mathematics. 5 (1), 9-19 (2020).

[19] Shrestha S., Gurung D. B. Finite Element Method Approach for Thermal Analysis of Female Breast Tissue Tumor Model. Journal of Applied Bioinformatics \& Computational Biology. 6 (3), (2017).

[20] Pennes H. H. Analysis of Tissue and Arterial Blood Temperature in resting forearm. Journal of applied physiology. 1, 93-122 (1948).

[21] Gurung D. B., Gokul K. C., Adhikary P. R. Mathematical Model of Thermal Effects of Blinking in Human Eye. International Journal of Biomathematics. 9 (1), 1-20 (2016).

[22] Gagnon D., Kenny G. P. Dose sex has an independent effect on thermoeffectors responses during exercise in the heat? J. Physiology. 590 (23), 5963-5973 (2014).

[23] Stephenson L. A., Margaret A. Thermoregulation in Women. Exercise and Sport Sciences Reviews. 21, 231-262 (1993).

[24] Rao S. S. The Finite Element Method in Engineering. Elsevier (2011).

[25] Reddy J. N. An Introduction to the Finite Element Method. McGraw-Hill Mechanical Engineering (2005).

[26] Sudarshan N. M., Ng E. Y. K. Surface Temperature Distribution of a Breast with and without Tumour. Computer Methods in Biomechanics and Biomedical Engineering. 2 (3), 187-199 (1999).

[27] Soni S., Tyagi H., Taylor R. A., Kumar A. The Influence of Tumour Blood Perfusion Variability on Thermal Damage During Nanoparticle-Assisted Thermal Therapy. International Journal of Hyperthermia. 31 (6), 615-625 (2015).

[28] Acharya S., Gurung D. B., Saxena V. P. Effect of Metabolic Reaction on Thermoregulation in Human Males and Females Body. Journal of Applied Mathematics. 4, 39-48 (2013).

[29] Makrariya A., Pardasani K. R. Finite Element Model to Study the Thermal Effect of Cyst and Malignant Tumor in Women's Breast During Menstrual Cycle under Cold Environment. Advances and Applications in Mathematical Sciences. 18 (1), 29-43 (2018). 
[30] Park S. J., Tamura T. Distribution of Evaporation Rate on Human Body Surface. Annals of Physiological Anthropology. 11 (6), 593-609 (1992).

\title{
Математичне моделювання змін температури в тканинах молочної залози з пухлиною/кістою та без неї під час менструального циклу
}

\author{
Шрешта С., Гурунг Д. Б., Гокул К. С. \\ Відділ математики Природничої школи, Університет Катманду, \\ Дюуліхель 45200, Непал
}

\begin{abstract}
На терморегуляцію жіночого організму людини впливають гормональні та фізіологічні зміни в організмі під час менструального циклу. Флуктуації гормонів естрогену та прогестерону, що виділяються у фолікулярній та лютеїновій фазах менструального циклу відповідно, відіграють важливу роль у зростанні проток грудей та молочних залоз. Дисбаланс цих гормонів викликає пухлину молочної залози/кісту. Базальна температура тіла, перфузія крові та швидкість обміну речовин вищі в лютеїновій фазі, ніж у фолікулярна фазі менструального циклу. У цій роботі припускається, що пухлина/кіста знаходиться у залозистому шарі. Двовимірне рівняння біологічного нагрівання Пеннеса розв'язано для виявлення змін температури в тканині молочної залози з пухлиною/кістою та без неї під час менструального циклу за допомогою методу скінченних елементів. Результати показують, що температура кожного шару тканини молочної залози в лютеїновій фазі вища, ніж у фолікулярній для випадку нормального стану, наявності пухлини та кісти.
\end{abstract}

Ключові слова: пухлина молочної залози, менструальний изикл, коливання темnератури, $M C E$. 